\title{
Study on culture conditions of several strains of toluene-degrading bacteria isolated from common ornamental houseplants
}

\author{
Nghiên cưu một số điều kiện nuôi cấy các chủng vi khuẩn phân giải toluene \\ phân lập tù một số cây cảnh phổ biến \\ Research article
}

Phan, Due Thanh*; Nguyen, Thi Cuc

Department of Biotechnology and Microbiology, Hanoi National University of Education, 136 Xuan Thuy Str., Cau Giay Dist., Hanoi, Vietnam

\begin{abstract}
This article studies the impact of some environmental conditions and the nutrition of culturing medium on the growth of bacteria and theirs capacity of toluene removal. The 5 bacterial strains isolated from leaf samples of three different common houseplants in Vietnam are Gram-negative, rod-shaped bacteria. The cells are single or arranged in chains. The cell size is relatively small and ranged from 0.7 to $2.5 \mu \mathrm{m}$. These bacteria prefer the incubating temperature from $28^{\circ} \mathrm{C}$ to $32^{\circ} \mathrm{C}$ and a neutral $\mathrm{pH} 6.5$ to 7.5 . They are able to assimilate different nitrogen and carbon sources. In the liquid SH1 medium containing 200ppm toluene five selected strains have shown the ability to degrade toluene at a rate of 12.8 to $75.2 \%$ in comparison with the control at $30^{\circ} \mathrm{C}$ at a speed of $200 \mathrm{rpm}$ for over 120 hours. These 5 studied strains are potentially useful in bioremediation strategies to remove airborne toluene.
\end{abstract}

5 chủng vi khuẩn có khả năng phân giải toluene được phân lập tù lá một số cây cảnh phổ biến ở Việt Nam là vi khuẩn $G(-)$, dạng trục khuẩn và kích thước tế bào tù̀ 0,7-2,5 um. Một số điều kiện môi truờng nuôi cấy thích hợp cho 5 chủng vi khuẩn nghiên cú gồm nhiệt độ $28^{\circ} \mathrm{C}-32^{\circ} \mathrm{C}, \mathrm{pH}$ 6,57,5, có khả năng đồng hoá nhiều nguồn nito và ba nguồn carbon khác nhau. Trong điều kiện môi trương dịch SH1 chúa 200ppm toluene, 5 chủng vi khuẩn này cho thấy khả năng phân giải toluene tù̀ 12,8 - 75,2\%. Đây là các chủng vi khuẩn có tiềm năng ứng dụng để loại bỏ toluene tù không khi ô nhiễm.

Keywords: bacteria, toluene, benzene, leaf, biodegradation, ornamental houseplants

\section{Introduction}

Every day human beings may face volatile airborne chemicals such as toluene and benzene in their own houses which have been introduced into the air by some of the materials used in making furniture such as paints and varnishes, and in electronic products. Due to the low transfer of air in these rooms toxic gases accumulate; this is the reason for the indoor air pollution often causing more serious effects on human health than outdoor air pollution [18]. Consequently, this affects human's health and causes a syndrome known as Sick Building Syndrome $[1,16,18]$.
Plants can absorb some pollutants through the cuticle and stomata on the leaf surface when exposed to the air $[4,5,7,8,9,15]$. With the additional presence of phytoremediating microorganisms on stems and leaves, it is supposed that the ability to detoxify substances on the plant will be greatly improved.

The application of bacteria in the degradation of aromatic hydrocarbon compounds such as toluene (TOL) and benzene (BEN) is effective and proving popular. Pseudomonas is the most common species of bacteria to have been studied in the decomposition of toluene $[2,3,11,17]$. Focusing on the ability to remove toxic chemicals from the air using microbial flora is a new trend regarded as a safer, more effective and cheaper method than others such as filter, absorbing. 
In this article, we investigate the ability to degrade toluene of 5 bacterial strains isolated from three common house plant specieș (Azadea indica, Ficus benjamina, Schefflera arboricola) and find out optimal culture conditions for their growth.

\section{Materials and methods}

\subsection{Materials}

Leaves used for bacterial isolation were randomly collected from three tree species incuding Azadea indica, Ficus benjamina and Schefflera arboricola, which were planted in the library of Hanoi National University of Education. Pure toluene $\left(\mathrm{C}_{6} \mathrm{H}_{5} \mathrm{CH}_{3}\right)$ and other chemicals used for this study were purchased from Sigma and Merck companies.

Leaf samples kept in aseptic nylon bags with labels recording collected time and location were transferred to the laboratory.

The isolating and culturing medium of $\mathrm{SH} 1$ comprises (g/L): $0.5 \quad \mathrm{~K}_{2} \mathrm{HPO}_{4} ; 0.5 \quad \mathrm{KH}_{2} \mathrm{PO}_{4} ; 1.0 \mathrm{NaCl} ; 1.0 \mathrm{NH}_{4} \mathrm{Cl}$; $2.0 \mathrm{MgSO}_{4} .7 \mathrm{H}_{2} \mathrm{O} ; 0.5\left(\mathrm{NH}_{4}\right)_{2} \mathrm{SO}_{4} ; 1.0 \mathrm{Na}_{2} \mathrm{SO}_{4}$. The solid medium of SH1 containing $20 \mathrm{~g}$ agar per litre, was used for culturing the bacteria. After sterilizing at $1 \mathrm{~atm}$ for 15 minutes, toluene (TOL) was added to the SH1 medium, which reached the concentration of $200 \mathrm{ppm}$.

\subsection{Methods}

\subsubsection{Enrichment}

The isolation experiments were carried out within the first 24 hours after sample collection. Three samples of $1 \mathrm{~g}$ of leaves for each tree species were finely crushed by a sterile porcelain mortar and pestle and filtered for extract. $5 \mathrm{ml}$ of each extract was added to a $250-\mathrm{ml}$ flask containing $50 \mathrm{ml}$ of SH1 liquid medium with $200 \mathrm{ppm}$ of TOL and incubated at $30^{\circ} \mathrm{C}, 200 \mathrm{rpm}$ for 120 to 168 hours. $10 \%$ of the first-time enriched liquid was transferred to a new $250-\mathrm{ml}$ flask containing the same content as the previous enriching time for the second enrichment. This process was repeated three times. The liquid of the $3^{\text {rd }}$ enrichment was diluted by distilled water from $10^{1}$ to $10^{7} .100 \mu 1$ diluted solution was suctioned by aseptic micropipette to spread on an aseptic plate of SH1 solid medium containing 200ppm of TOL and incubated at $30^{\circ} \mathrm{C}$ for 72 to 120 hours.

To purify the bacterial strain, well grown bacterial colonies different in morphologies were selected and restreaked on the same medium plates 2 or 3 times. All pure bacterial strains were cultivated on $\mathrm{SH} 1$ solid medium and stored at $4^{\circ} \mathrm{C}$.

\subsubsection{TOL biodegradation}

To analyse the ability of TOL biodegradation by the isolated bacterial strains, each bacterial strain was incubated with $20 \mathrm{ml}$ of SH1 liquid medium containing 200ppm TOL at $30^{\circ} \mathrm{C}$ for 120 hours, and then the culture was extracted with $180 \mathrm{ml}$ of acetone and filtered for the liquid. Based on the electronic shift on $\Pi$ orbitals of the double bond in the aromatic ring of the TOL, concentrations of TOL in the SH1 liquid medium with and without bacteria were determined by using the visible ultraviolet spectrophotometer UV-VIS GBC-CINTRA 4 at a wavelength of $260 \mathrm{~nm}$.

\subsubsection{Effect of nitrogen, carbon sources, temperature and $\mathrm{pH}$ on the growth}

To study the effect of nitrogen sources on the growth of selected strains: $0.2 \mathrm{ml}$ of the liquid medium incubating each activated strain was added to the flask containing $15 \mathrm{ml}$ of liquid SH1 medium with 7 different nitrogen sources: yeast extract, monosodium glutamate (MSG), $\mathrm{NH}_{4} \mathrm{Cl}, \mathrm{NH}_{4} \mathrm{HCO}_{3},\left(\mathrm{NH}_{4}\right)_{2} \mathrm{SO}_{4}, \mathrm{KNO}_{3}$, and $\mathrm{NaNO}_{3}$. All the above tubes were kept shaking at $200 \mathrm{round} / \mathrm{min}$ at $32^{\circ} \mathrm{C}$. After 48 hours, each strain was estimated for OD at a wavelength of $610 \mathrm{~nm}$.

Research of the effect of carbon sources on the growth of selected strains was designed as same as the experiment to investigate the efectt of nitrogen sources with $\mathrm{NH}_{4} \mathrm{Cl}$ as nitrogen source and 3 different carbon sources: toluene, xylene, benzene. After 24-hours and 48-hours incubating, the OD value at a wavelength of $610 \mathrm{~nm}$ was measured for each strain.

To investigate the effect of temperature, each studied strain incubated in the $\mathrm{SH} 1$ liquid medium with $\mathrm{NH}_{4} \mathrm{Cl}$ and TOL as nitorgen and carbon sources was kept at 5 different temperatures $26^{\circ} \mathrm{C}, 28^{\circ} \mathrm{C}, 30^{\circ} \mathrm{C}, 32^{\circ} \mathrm{C}, 34^{\circ} \mathrm{C}$ for 48 hours. Then OD value at a wavelength of $610 \mathrm{~nm}$ of medium incubated with each studied strain was evaluated. The effect of $\mathrm{pH}$ on the bacterial growth was carried out for each strain incubating in $\mathrm{SH} 1$ liquid medium at $30^{\circ} \mathrm{C}$, in the $\mathrm{pH}$ range of 5-8 with 0.5 interval. The OD value at a wavelength of $610 \mathrm{~nm}$ was measured after 48 -hours culturing.

\section{Results and discussion}

\subsection{Several morphological characteristics of colonies and cells of selected strains}

Several morphological characteristics of the colony and of the cells' formation by 5 selected strains including D21, D6, S7, D23, and D24 were identified. Two strains, D21 and D24, show an ability to grow and thrive. The 5 strains are all Gram-negative bacteria. The colony formation of three strains D21, D23, and D24 are fairly similar, however, the colony surface of strain D24 is shinier than that of D23 and D21. The cell morphology of all selected strains is bacilli and the cell size ranged variously (Figure $1)$. 


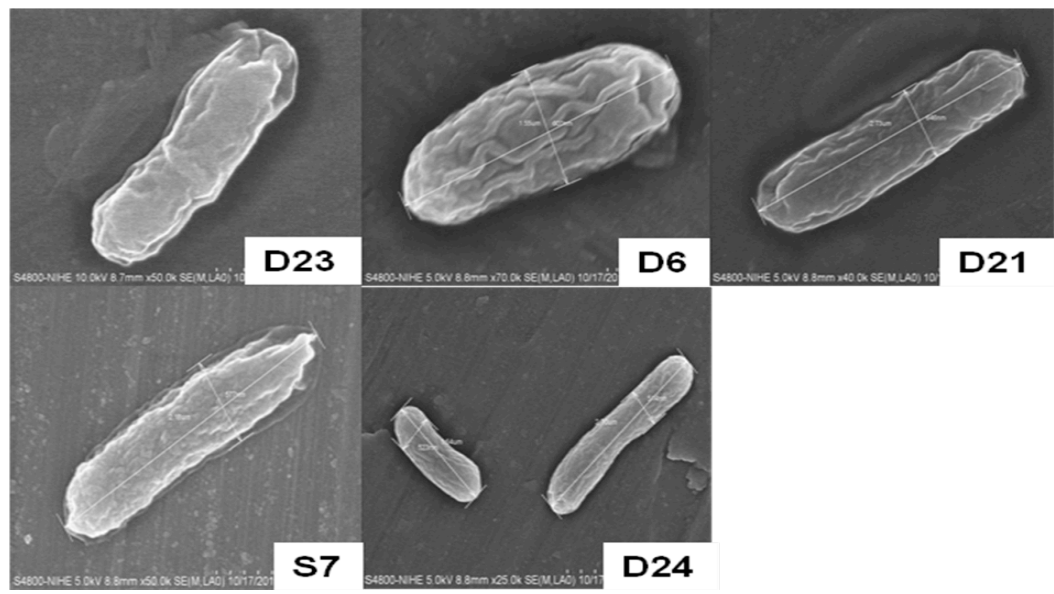

Figure 1. Cellular morphology of 5 bacterial strains (SEM4800X)

\subsection{Growth dynamics of studied strains}

Growth dynamics of a species reflects the growth and reproductive capacity of the species in a certain time frame. Depending on the form of continuous culture (microbial culturing medium with added nutrients) or discontinuous culture (microbial culture medium without added nutrients) it can be seen that their growth dynamics are different.

During growth, the studied strains were using the TOL as a source of carbon and energy. Growth dynamics of the 5 selected strains are quite similar. During first 12 hours, the culture was in the lag phase and at this time point the number of cells in the culture medium increased steadily but at a much slower pace. It could be explained that the bacteria become familiar with the medium conditions. During this phase, nutrients and energy were accumulated for the next growth phase. From 12 to 48 hours, the culture was in the log phase. The number of cells increased rapidly and reached the maximum value after 48 hours. 12 hours after incubating, the culture medium began to change its color. From 48 to 72 hours, the culture was in the equilibrium phase, the number of cells was stable in the culture medium; and the number of dead cells and the number of newly born cells were relatively equivalent. After 72 hours, the decline phase started. In this phase, the number of dead cells was higher than the number of new cells. Thus, the total number of cells in the culture medium decreased rapidly, caused by nutrient depletion and toxic product accumulation during metabolism increasing. The number of bacterial cells increased and reached a peak after 48 hours of culturing. It was supposed that at this time point the cells reached the bestactivated level because the bacterial growth rate was maximized. However, it was found that from 48 hours onwards the number of cells was highest, and as a result, the amount of TOL consumed by bacteria was very high. As the supply of carbon and energy was gradually decreased, the equilibrium phase was rapid. From 72 hours onwards the culture medium was depleted of nutrients, and the decline phase began. Thus, the appropriate incubation time was approximately $18-24$ hours, at which the number of bacterial cells grows exponentially. From the above results, the optimum time for bacterial cell activation was identified and was used for further research.

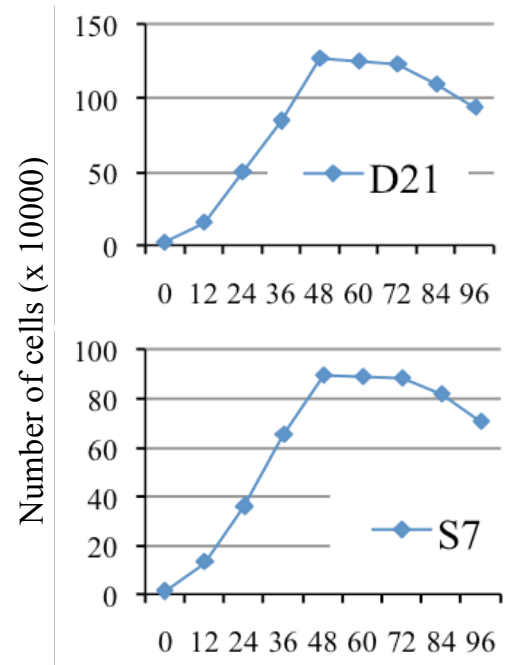

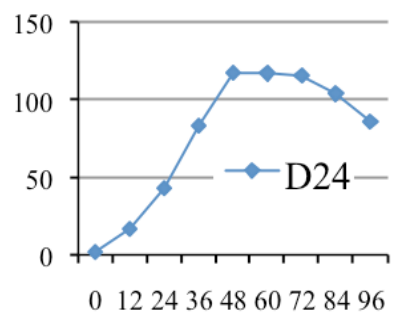

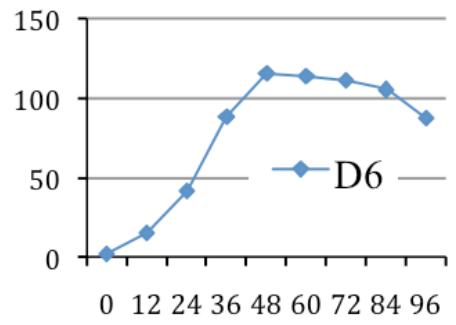

Incubating time (hours)

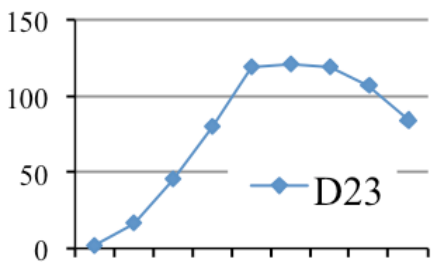

01224364860728496

Figure 2. Growth dynamics of the selected bacterial strains 


\subsection{Ability to consume TOL of the selected strains}

Toluene degradability is different among these 5 studied strains (Fig 3). After 5 days of incubating in the liquid medium of SH1 with 200 ppm TOL added, the highest rate of TOL degradation was performed by strain D21 (75.2\%), followed by strains D24, D6, and D23 ( 40\%) and the lowest rate was observed in S7 (12.8\%) compared to the rate performed by the control containing no bacteria $(9 \%)$. The different strains of bacteria have structural and physiological differences. The difference in their TOL degradability may be due to different TOL oxidation operons they carry.

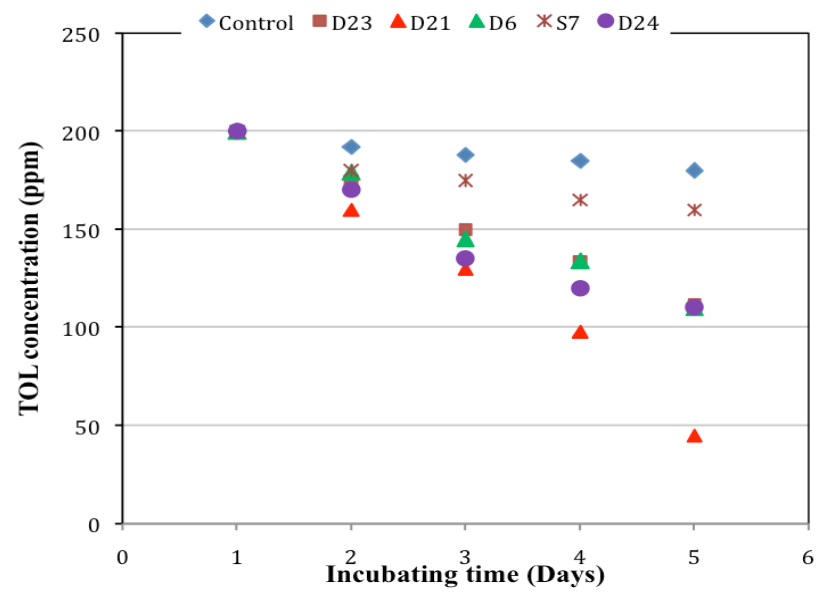

Figure 3. The ability to use TOL of 5 bacterial strains during 5-day incubation on SH1 medium with TOL added

According to Shinoda et al. (2005), TOL can be metabolized by different aerobic and anaerobic bacteria expressing either of genes for oxidative enzymes: toluene dioxygenase (tod) and benzylsuccinate synthase (BSS). These two genes encode for key enzymes in the metabolism of toluene under aerobic and anaerobic conditions: toddigesting enzymes degrade TOL under aerobic conditions, while BSS - digesting enzymes degrade TOL under both aerobic and anaerobic conditions. Parales et al. (2000) described TOL decomposition by Pseudomonas putida F1 through toluene 2,3-dioxygenase, an enzyme responsible for aromatic ring oxidation of toluene, and combination of the two oxygen atoms of the molecule.

\subsection{Effects of several culturing parameters on growth of selected strains}

\subsection{1 $\mathrm{pH}$ value}

The $\mathrm{pH}$ of the medium affects the separation of the ions, the structure and activity of the protein and is crucial to the growth and biosynthesis of the bacterial substances. The five selected strains were able to grow at $\mathrm{pH}$ levels from 5.0 to 8.0. These strains grew better at a $\mathrm{pH}$ of around 7.0. Both strains D24 and S7 achieved the best growth at $\mathrm{pH} 7.5$, while the three others grew well at $\mathrm{pH} 7$
(Figure 4). This was similar to the results of a previous study showing that Pseudomonas species with the ability to remove TOL and is able to grow at the $\mathrm{pH}$ ranges from 6-8 and $\mathrm{pH}$ of 7 is best for its growth $[2,13,15]$. Based on the experimental results, $\mathrm{pH} 7.0$ was selected to conduct next experiments.

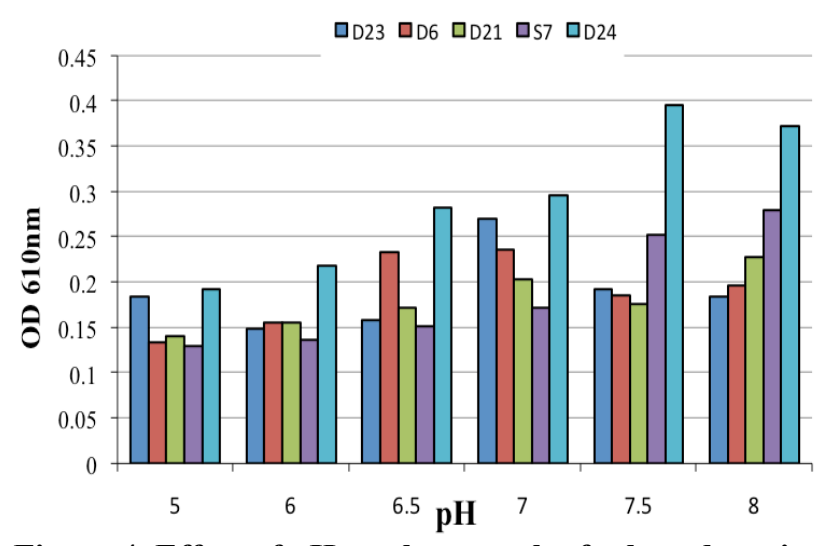

Figure 4. Effect of $\mathrm{pH}$ on the growth of selected strains

\subsubsection{Incubation temperature}

Figure 5 showed that the 5 selected strains grew at all temperatures conducted in the experiment. The optimal temperature for the growth of five studied strains ranged from $28^{\circ} \mathrm{C}$ to $32^{\circ} \mathrm{C}$, in which the strains of D23, D6, and $\mathrm{S} 7$ performed the best growth at $30^{\circ} \mathrm{C}$ and D21 and D24 at $32^{\circ} \mathrm{C}$. It is suggested that studied strains may belong to the mesophilic bacteria. The results were also consistent with the study by Chang et al. (1997), who found that the most suitable temperature for growth of Pseudomonas sp. D8, which has an ability to decompose TOL was $30^{\circ} \mathrm{C}$.

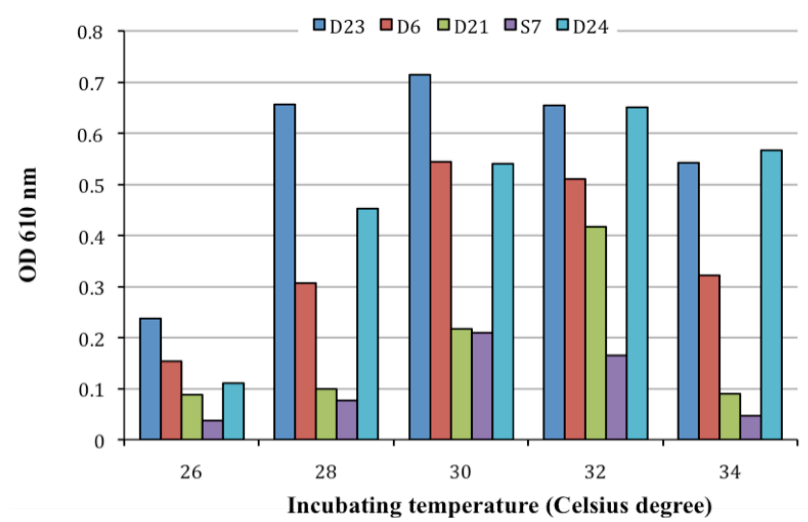

Figure 5. Effect of temperature on the growth of selected strains

\subsubsection{Nitrogen sources}

Nitrogen is an essential element for creating protein, so nitrogen source plays an important role in the growth and development of bacteria. Yeast extract was regarded as the suitable nitrogen source for culturing bacteria. For the group of TOL biodegradable bacteria, the yeast extract as a nitrogen source help bacteria attain good growth but may have reduced the ability of TOL decomposition. The majority of TOL decomposition bacteria use TOL substrate as the sole carbon and energy source [7]. 
Figure 6 revealed that most studied strains grew better on SH1 medium with yeast extracts as a nitrogen source compared to 6 other nitrogen sources. However, the D21 strain grew best on the nitrogen source of MSG. Compared to nitrate such as $\mathrm{KNO}_{3}, \mathrm{NaNO}_{3}, \mathrm{NH}_{4} \mathrm{NO}_{3}$, ammonium such as $\mathrm{NH}_{4} \mathrm{Cl},\left(\mathrm{NH}_{4}\right)_{2} \mathrm{SO}_{4}, \mathrm{NH}_{4} \mathrm{HCO}_{3}$ were more suitable to be used as a nitrogen source for the growth of selected strains. This suggested that the studied strains assimilate ammonium better.

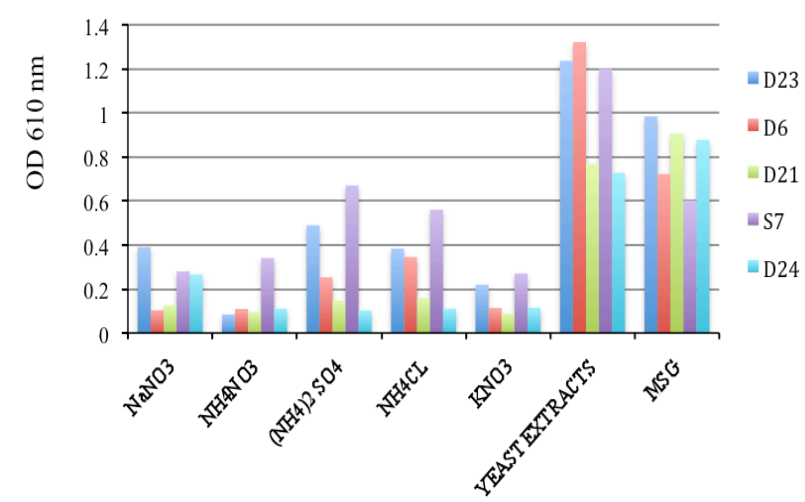

Figure 6. Effect of the nitrogen source on the growth of selected strains

\subsubsection{Carbon sources}

The majority of bacteria that have toluene biodegradability are supposed to be capable of resolving other volatile organic compounds (VOCs) such benzene, xylene. Strains used VOCs as carbon and energy source only.

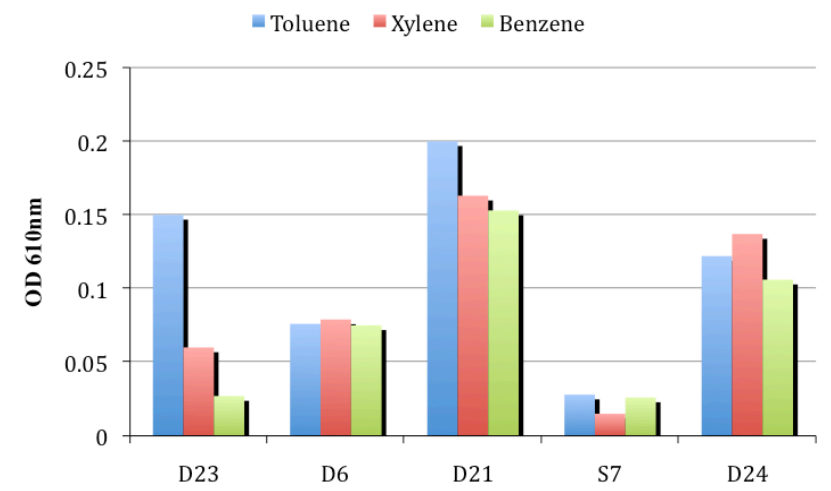

Figure 7. Effect of carbon sources on the growth of selected strains

The results from Figure 7 showed that most strains could consume all provided carbon sources. The carbon source had a positive impact on the growth of the majority of the strains studied. Especially, two strains D21 and D24 had the ability to assimilate three aromatic hydrocarbon sources including toluene, benzene and xylene (BTX) as energy and carbon sources in their metabolism. These results allowed preliminary assessment of the role of the studied bacteria in the decomposition of BTX compounds and its role in biological enrichment strategies in order to remove toluene from air pollution.

Recently, there have been many studies on transfer of genes, which code for enzyme metabolizing TOL or other aromatic hydrocarbons to create strains of bacteria that have the ability to degrade a variety of hydrocarbons. Pseudomonas putida NCIB 9816-4 is capable of cancelling napthalene [12], Pseudomonas rhodesiae KK1 has the ability to grow on a substrate source mixing three types of PAH anthracene, naphthalene and phenanthrene [6]. In 2005, Otenio et al. studied and assessed the metabolic activity of aromatic hydrocarbons by Pseudomonas putida CCMI 852 that carries a TOL plasmid on minimal mineral medium containing each individual hydrocarbon BEN or TOL or XYL, or containing mixtures of BTX. The strain showed its ability to degrade toluene and xylene in the BTX mixture. Strains D21 and D24 may be potential genetic resources for further research in creating strains of bacteria capable of removing a variety of aromatic hydrocarbons in the future.

\subsection{Effect of initial TOL concentration on the growth of D21}

Each microorganism has a certain threshold for a toxic substance at which it can grow. Depending on the strain, as well as the toxin, this threshold may be higher or lower. In the previous experiment for investigating the ability to consume TOL, the strain D21 has the highest ability to use TOL as a source of carbon and energy.

To find out the preliminary threshold of TOL for growth, strain D21 was incubated in the liquid SH1 medium containing TOL at various concentrations that ranged from 50 to $300 \mathrm{ppm}$. Results in Figure 8 showed that, after 5 days of incubating, strain D21 grew weakly at the concentration of $300 \mathrm{ppm}$. The optimal TOL concentrations for the growth of strain D21 ranged from $100 \mathrm{ppm}$ to 200 ppm.

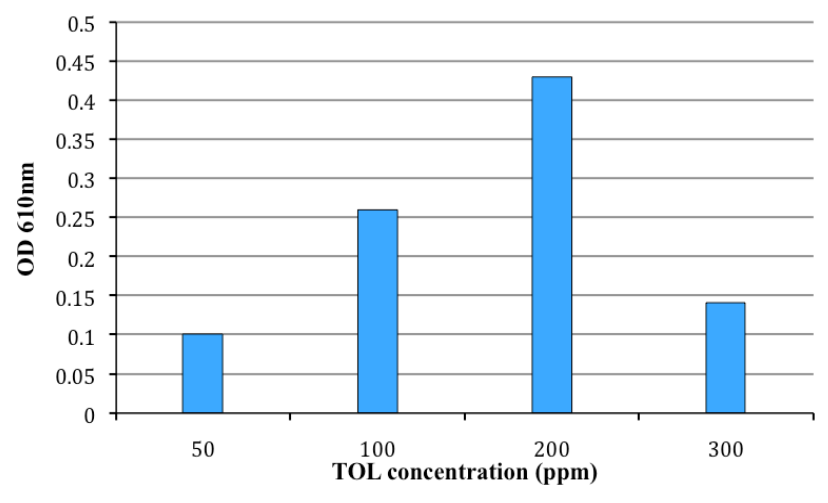

Figure 8. Effect of TOL concentration on the growth of D21

This result was consistent with the study by Chang et al. (1997) on Pseudomonas sp. D8 isolated from underground areas contaminated with toluene and benzene (individually or mixed in proportion) at a concentration of $100 \mathrm{ppm}$.

\section{Conclusion}

Five bacterial strains isolated from leaf samples of three common ornamental plant species including Azadea indi- 
ca, Ficus benjamina and Schefflera arboricola, performed the ability of toluene degradation were selected.

After 5 days of incubation at $30^{\circ} \mathrm{C}$ and $200 \mathrm{rpm}$ in $\mathrm{SH} 1$ medium with $200 \mathrm{ppm}$ toluene added, the 5 selected strains were able to assimilate toluene. Among them, D21 had the best ability to degrade toluene $(75.2 \%)$. These 5 studied strains are potentially useful in bioremediation strategies to remove airborne toluene. It is necessary to conduct further research using bacteria-plant combinations for eliminating airborne toluene as the next step.

\section{References}

[1] Brown S. K., Sim M. R., Abramson M. J., Gray C. N. (1994) Concentrations of volatile organic compounds in indoor air - a review. Indoor Air - Int. J. Indoor Air Qual. Clim. 4, 123-134.

[2] Chang B.V., Wu W.B. \& Yuan S. Y. (1997) Biodegradation of benzene, toluene, and other aromatic compounds by Pseudomonas sp. D8. Chemosphere 35(12), 2807-2815.

[3] Farrell, R.L., Rhdes, P.L. and Aislabie, J. (2003) Toluene-degrading Antarctic Pseudomonas strains from fuel-contaminated soil. Biochemical and Biophysical Research Communication 312, 235-240.

[4] Giese M, Bauer-Doranth U., Langebartels C., Sandermann H. Jr. (1994) Detoxification of formaldehyde by the spider plant (Chlorophytum comosum L.) and by soybean (Glycine max L.) cell-suspension cultures. Plant Physiol. 104, 1301-1309.

[5] Jen M.S., Hoylman A.M.; Edwards N.T. and Walton B.T. (1995) Experimental method to measure gaseous uptake of 14C-toluene by foliage. Environ. Exp. Bot. 35, 389-398.

[6] Brown S. K., Sim M. R., Abramson M. J., Gray C. N. (1994) Concentrations of volatile organic compounds in indoor air - a review. Indoor Air - Int. J. Indoor Air Qual. Clim. 4, 123-134.

[7] Chang B.V., Wu W.B. \& Yuan S. Y. (1997) Biodegradation of benzene, toluene, and other aromatic compounds by Pseudomonas sp. D8. Chemosphere 35(12), 2807-2815.

[8] Farrell, R.L., Rhdes, P.L. and Aislabie, J. (2003) Toluene-degrading Antarctic Pseudomonas strains from fuel-contaminated soil. Biochemical and Biophysical Research Communication 312, 235-240.

[9] Giese M, Bauer-Doranth U., Langebartels C., Sandermann H. Jr. (1994) Detoxification of formaldehyde by the spider plant (Chlorophytum comosum L.) and by soybean (Glycine max L.) cell-suspension cultures. Plant Physiol. 104, 1301-1309.

[10] Jen M.S., Hoylman A.M., Edwards N.T. and Walton B.T. (1995) Experimental method to measure gaseous uptake of 14C-toluene by foliage. Environ. Exp. Bot. 35, 389-398.

[11] Kahng H.Y., Nam K., Kukor J.J., Yoon B.J., Lee
D.H., Oh D.C., Kam S.K. and Oh K.H. (2002) PAH utilization by Pseudomonas rhodesiae KK1 isolated from a former manufactured-gas plant site. Microbiol. Biotechnol. 60(4), 475-80.

[12] Keymeulen R., Schamp, N. and Van Langenhove, H. (1995) Uptake of gaseous toluene in plant leaves: a two-compartment model. Chemosphere, 31(8), 3961-3975.

[13] Kondo, T., Hasegawa, K., Uchida, R., Onishi, M., Mizukami, A., Omasa, K. (1996) Absorption of atmospheric formaldehyde by deciduous broad-leaved, evergreen broad-leaved and coniferous tree species. Bull. Chem. Soc. Jpn. 69, 3673-3679.

[14] Omasa K., Tobe K. , Hosomi M. and Kobayashi M. (2000) Absorption of ozone and seven organic pollutants by Populus nigra and Camellia sasanqua. Environ Sci Technol. 34, 2498-2500.

[15] Otenio M.H., Silva M.T.L.D, Marques M.L.O., Roseiro J.C., Bidoia E.D. (2005) Benzene, toluene and xylene biodegradation by Pseudomonas putida CCMI 852. Brazilian Journal of Microbiology 36, 258-261.

[16] Parales, R.E., Ditty, J.L. and Harwood, C.S. (2000) Toluene-degrading bacteria are chemotactic towards the environmental pollutants benzene, toluene, and trichloroethylene. Appl. Environ. Microbiol. 66 (9), 4098-4104.

[17] Park W., Jeon C.O., Cadillo H., DeRito C. and Madsen E.L. (2004) Survival of naphthalene-degrading Pseudomonas putida NCIB 9816-4 in naphthaleneamended soils: toxicity of naphthalene and its metabolites. Microbiol Biotechnol. 64(3), 4293539.

[18] Peishi S., Xianwan Y., Ruohua H., Bing H. and Ping Y. (2002) A new approach to kenetics of purifying waste gases containing volatile organic compounds (VOC) in low concentration by using the biological method. J. Cleaner Production 12, 95-100.

[19] Shinoda Y., Akagi J., Uchihashi Y., Hiraishi A., Yukawa H., Yurimoto H., Sakai Y. and Kato N. (2005) Anaerobic degradation of aromatic compounds by Magnetospirillum strains: isolation and degradation genes. Biosci Biotechnol Biochem 69, 1483-1491.

[20] Ugrekhelidze, D., Korte, F. and Kvesitadze, G. (1997) Uptake and transformation of benzene and toluene by plant leaves. Ecotoxicol. Environ. Safety 37, 24-29.

[21] US-GAO (United States General Accounting Office), 1999. Indoor pollution.

[22] Vermace M.E., Christensen R.F., Parkin G.F. and Alvarez P.J.J. (1996) Research note: Relationship between the concentration of denitrifiers and Pseudomonas spp. in soils implications for BTX bioremediation. Wat. Res. 30, 3139-3145. 
[23] Wargocki P., Wyon D.P., Sundell J., Clausen G., Fanger P.O. (2000). The effects of ourdoor air supply rate in an office on perceived air quality, Sick
Building Syndrome (SBS) symptoms and productivity. Indoor Air-Int. J. Indoor Air Qual. Clim. 10, 222-236. 